\title{
Mapping Sustainable Finance: A Detailed Analysis of Banks in Indonesia
}

\section{Inten Meutia** (i) | Shelly Febriana Kartasari' | Zulnaidi Yaacob² (i) | Murugesh Arunachalam ${ }^{3}$}

\author{
${ }^{1}$ Universitas Sriwijaya, Faculty of Economics, Palembang, Indonesia \\ ${ }^{2}$ Universiti Sains Malaysia, School of Distance Education, Penang, Malaysia \\ ${ }^{3}$ University of Waikato, School of Accounting, Finance and Economics, Hamilton, New Zealand \\ * Correspondence to: Inten Meutia, Universitas Sriwijaya, Faculty of Economics, Jl. Raya \\ Palembang - Prabumulih Km. 32 Indralaya, Palembang 30662, Indonesia. \\ E-mail: intenmeutia@unsri.ac.id
}

\begin{abstract}
This study aims to map the conformity of sustainability reports (SRs) for the BUKU 3 and BUKU 4 bank groups with regulations issued by the Indonesian Financial Services Authority (OJK). The research is exploratory, considering that FSA Regulation number 51 of 2017 was not applied until 2019. It represents a quantitative descriptive study employing a content analysis approach to explore and analyze data and factual input from SRs. The data used are drawn from the 2017 report concerning seven BUKU 3 banks and five BUKU 4 banks. This study found that the contents of the bank reports, with the components required by POJK number 51 of 2017 , concerning the sustainable financial action plan and the SR, did not fully meet the requirements of the POJK. Using cross-tabulation analysis, we found that the average bank has a good, sustainable financial action plan and suitable sustainability reporting above $90 \%$. It also has higher total assets, CAR/KPPM, ROA, and ROE ratios than banks with lower index suitability. This finding implies a potential relationship between SR compliance levels and bank financial characteristics. Overall, the conformity level of BUKU 4 banks is better than that of BUKU 3 banks.
\end{abstract}

Keywords: sustainable development, sustainable finance, sustainability report.

Article info: Received 26 September 2019 | revised 2 November 2019 | accepted 7 June 2020

Recommended citation: Meutia, I., Kartasari, S. F., Yaacob, Z., Arunachalam, M. (2020). Mapping Sustainable Finance: A Detailed Analysis of Banks in Indonesia. Indonesian Journal of Sustainability Accounting and Management, 4(1), 13-27. https://doi.org/10.28992/ijsam.v4i1.110.

\section{INTRODUCTION}

Sustainable development is an issue that developed since the launch of the "2030 Agenda for Sustainable Development" in New York in September 2015. This agenda is an action plan to support development that integrates economic, social, and environmental interests through 17 development goals and 169 targets. Sustainable development is about maintaining the welfare of humanity and the natural environment by trying not to reduce the possibilities for future generations and without losing the economic sustainability of the current generation. 
Indonesia has followed up on this International agreement through the Republic of Indonesia Presidential Regulation No. 59 of 2017 concerning the achievement of sustainable development goals. Sustainable development aims to maintain the increase in community economic welfare in a sustainable manner, the sustainability of the social life of the community, the quality of the environment, as well as inclusive development and maintain the life quality improvement from one generation to the next.

The Government of Indonesia has shown support for the issue of sustainable development through the Presidential Regulation of the Republic of Indonesia Number 59 of 2017 regarding the implementation of sustainable development goals achievement. In line with that, the Indonesian Financial Services Authority issued a 2015-2019 Sustainable Finance Roadmap in December 2014. In the Sustainable Finance Roadmap, one of the things that must be realized is the existence of specific and binding regulations for all financial service sector actors related to the implementation of sustainable finance in Indonesia.

Jeucken (2001) in his book Sustainable Finance and Banking, said that sustainable development has an important strategic dimension for banks. Threats and opportunities for banks that arise from the community's push towards sustainable development can divide into several categories with a series of criteria, from risk reduction to profitability, and from purely business reasons to ideological reasons.

Subsequently, in 2017, the Financial Services Authority issued POJK number 51/POJK 03/2017 concerning the Implementation of Sustainable Finance for Financial Services Institutions (LJK), Issuers, and Public Companies. The direction of the Sustainable Finance regulation application is to encourage the creation of Sustainable Finance in the financial services sector that supports economic, social and environmental sustainability in the implementation of the development process in Indonesia.

Various countries in the world have made sustainable finance policies. The policies were issued by the Central Bank, such as in China, India, Bangladesh, Nigeria, and Brazil. While countries such as Japan, the Netherlands, and Germany have first applied voluntarily and were supported by the government with various supporting policy instruments such as credit/financing, investment, and fiscal policy support (Hadad, 2015).

POJK 51 of 2017 requires financial service institutions to implement sustainable finance by making a Sustainable Financial Plan and Sustainability Report every year. This regulation comes into force on January 1 , 2019, especially for banks in the category of BUKU 3, BUKU 4, and foreign banks. They are required to submit a report no later than December 31, 2019. Gradually this regulation will apply to banks BUKU 1 and BUKU 2 in the following year (Financial Services Authority, 2017).

This research study uses the legitimacy theory approach in describing the relationship between companies and the government (OJK) as a regulator. POJK number 51 of 2017 requires banks to fulfill obligations regarding sustainability. In this case, the company (bank) seeks to gain legitimacy from the regulator so that its existence is not disrupted.

From an organizational perspective, legitimacy defined by Lindblom (1994): "a condition or status which exists when an entity's value system is congruent with the value system of the larger social system of which the entity is a part. When a disparity, actual or potential, exists between the two value systems, there is a threat to the entity's legitimacy."

Legitimacy is a relative concept - that is, relative to the social system in which the entity operates and is a determined time and place. Suchman (1995) stated that, "Legitimacy is a generalized perception or assumption that the actions of an entity are desirable, proper, or appropriate within some socially constructed system of norms, values, beliefs, and definitions." The central premise of the theory of legitimacy is that organizations can maintain their operations only insofar as they have the support of society. Organizations that are considered by the community following the expectations of the community will receive support from the local community. In 
particular, there is an assumption that the survival of an organization threatened if the community sees the organization tends to violate its social contract.

Deegan (2014) states that when the community considers that the organization operates in unacceptably or in an illegal way, the community will effectively revoke the organization's contract to continue its operations. Revocation of this contract can be proven through, for example, consumers reducing or eliminating the demand for business products, suppliers eliminating labor supply and financial capital for business, or constituents lobbying the government to increase taxes, enacting taxes or laws to prohibit actions that are not under people's expectations. Based on the view of legitimacy theory, it is crucial for the financial services industry, especially banks, to respond well to the rules on sustainable finance. Failure to respond to this rule will make them lose legitimacy in the community. Especially considering that sustainable finance, which is part of sustainable development, is an issue that has attracted the attention of the global world community.

The book titled Silent Spring by Rachel Carson in 1962 inspired the United Nations to hold a conference on the environment on June 5, 1972, in Stockholm. Silent Spring tells about a lonely life caused by the dangers of environmental pollution that can no longer be controlled (Jameson, 2012). The commitment at the conference gave birth to the idea of sustainable development.

Brundtland Report published by the World Commission on Environment and Development (WCED) in 1987 emphasized the concept of sustainable development as 'development that meets the needs of the present without compromising the ability of future generations to meet their own needs' (United Nations World Commission on Environment and Development, 1987). WCED emphasizes the essential goals of environmental and development policies based on the concept of sustainable development. This includes reviving growth; change the quality of growth; fulfill essential needs for work, food, energy, water, and sanitation; ensuring sustainable population levels; preserving and enhancing the resource base: reorienting technology and managing risk; and combining environment and economy in decision making (United Nations World Commission for Environment and Development, 1987). To support the concept of sustainable development, UNEF in 1992 issued a Statement of Commitment by the Financial Institutions on Sustainable Development, which followed up with the establishment of the UNEF. Financial Initiative. The UNEF Financial Initiative aims to provide policy targets and agreed commitments by expressing support for the concept of financing and investment to support sustainable development. The term sustainable finance is the implementation of credit management/financing and investment in all factors of economic, social, and environmental risk in a sustainable manner. The policy must be part of the financial services industry portfolio (Jeucken, 2001).

A broader definition provided by the EU High-Level Expert Group on Sustainable Finance. Interim Report, July 2017 (High-Level Expert Group on Sustainable Finance, 2018), namely: 1. Integrating ESG factors in financial decisions; 2. Finance that fosters sustainable economic, social, and environmental development; 3. A stable financial system that addresses long-term educational, economic, social, environmental problems, including sustainable employment, pension financing, technological innovation, infrastructure construction, and climate change mitigation.

The application of the principle of Sustainable Finance is a real commitment from Indonesia to the international world by providing funding sources to mitigate and adapt to climate change. According to POJK 51 of 2017, sustainable finance is comprehensive support from the financial services sector to create sustainable economic growth by aligning economic, social, and environmental interests. This POJK confirms that Financial Services Institutions and Public Companies must implement Sustainable Finance in the business activities of Financial Services Institutions and Public Companies. 
Although the concept of sustainable development or sustainable finance has been developing for a long time, based on the author's knowledge, there is still minimal research carried out to examine this issue more deeply. Some research on sustainability is still a discussion at the level of concepts including research conducted by Aliyu et al. (2016), Hashim et al. (2015), Kumar and Prakash (2018), Pratiwi (2016), Shamshad et al. (2018), Soppe (2004), Tan et al. (2017), and Wolfson et al. (2013). The limitations of earlier research studies can be understood, considering that sustainable finance is still a new issue, especially in developing countries.

A research study by Soppe (2004) presents and illustrates the concept of sustainable corporate finance. Sustainability is an established concept in the discipline of environmental economics and business ethics. This research uses a broader definition of what is called "company" to explain the term sustainability in the financial literature. This paper treats sustainable corporate finance (SCF) as a multi-attribute approach in which financial, social and environmental elements are interrelated and integrated. The paper concludes that finance as a discipline requires a multifaceted approach instead of the present one-dimensional risk and return focus.

The research (Wolfson et al., 2013) aims to describe the reciprocal perspectives on sustainability and services and characterize them to design and develop services that are more sustainable and to promote overall change toward sustainability. The researchers' findings suggest that sustainable services must provide the core value of services with sustainability and recruit customers as suppliers of sustainability for future generations.

Research conducted by Tan et al. (2017) on Maybank tries to uncover the reasons that motivate Maybank to implement sustainable banking operations-using a case study approach based on primary data collected through a series of qualitative interviews with 35 bankers from various departments. It found that the reasons that moved Maybank to implement sustainable banking operations were driven by macro, meso, and micro-level movers.

Another study conducted by Kumar \& Prakash (2018) aims to study the level of sustainable banking adoption, and the extent to which banks in India do the same. For this reason, the banks studied were ranked and categorized based on their sustainability banking performance. The study found that the highest priority for banks were those directly related to their business operations such as financial inclusion, financial literacy, and energy efficiency. Banks focus more on handling the social dimension of sustainability in banking rather than the critical dimension of sustainable banking, namely, environmental management, development of green products and services, and sustainability reporting.

Research studies on sustainable banking were also conducted by Shamshad et al. (2018). The purpose of this study is to identify the critical success factors for sustainable development in the Indian banking sector and develop models for Indian banks using interpretive structural modelling (ISM). This research suggests several essential steps for sustainability for Indian banks.

Previous studies have shown that the issue of sustainable finance has become a global issue and is developing in several countries. Research on sustainable financial problems in Indonesia is still minimal. Perhaps because POJK is relatively new and not many banks have implemented it. Therefore, this research study will contribute to the development of sustainable finance, especially in Indonesia and the world in general. Specifically, this research will reveal and identify the readiness of banks in Indonesia in responding to the issue of sustainable finance.

Since POJK number 51/2017 will implement in several stages, banks in Indonesia must immediately prepare themselves to comply with the POJK number 51/2017. For this reason, this research is important to assess the readiness of banks in Indonesia, especially BUKU 3 and BUKU 4 banks, in responding to the issue of this sustainability report (SR). This research formulates the problem as follows: How far is the readiness of BUKU 3 and BUKU 4 banks in implementing sustainable finance based on POJK regulation number 51 of 2017. 


\section{METHODS}

This research is a quantitative descriptive study that uses a content analysis approach in exploring and analyzing data and factual input from SRs. To analyze the readiness of banks in implementing sustainable finance, a content analysis approach is carried out. A content analysis approach is an approach commonly used in studies that examine the content of a report (Krippendorff, 2004). This approach widely used in accounting research (Alves, 2011; Beck et al., 2010; Frazier et al., 1984; Manurung \& Basuki, 2010; Meutia \& Putra, 2017; Sydserff \& Weetman, 2002; Unerman, 2000).

The content analysis carried out to identify the contents of the sustainability action plan (RAKB) and SR to determine the extent of conformity between what has been reported by the bank and what is required by POJK number 51 of 2017. Table 1 illustrates the components of the RAKB based on POJK number 51 of 2017. To identify bank sustainability practices, data sourced from SRs from seven BUKU 3 banks and five BUKU 4 banks in Indonesia in 2017 used in this study. On the basis of data in 2017, there were five BUKU 4 banks and 23 BUKU 3. However, out of the 23 BUKU 3, only seven banks have SRs. Through information from the SR, this research study can provide a complete picture of sustainability reporting practices in banks in Indonesia. Further, we can see how far these banks can implement what is required by POJK number 51 of 2017. BUKU 3 bank is a bank with

Table 1 Components of Sustainable Financial Action Plan (RAKB)

\begin{tabular}{|c|c|c|}
\hline A & Executive summary & \\
\hline A 1 & Achievement of the Sustainable Financial Action Plan & \\
\hline A 2 & Vision and mission & \\
\hline A 3 & Objectives of the Sustainable Financial Action Plan & \\
\hline A 4 & Programs implemented in the Financial Action Plan & \\
\hline A 5 & Resource allocation & \\
\hline A 6 & A person responsible for the implementation & 6 \\
\hline B & The process of preparing a Sustainable Financial Action Plan & \\
\hline B 1 & $\begin{array}{l}\text { Statement of parties' involvement in preparing the Sustainable Financial Action Plan and referral to the } \\
\text { preparation of Plan }\end{array}$ & 1 \\
\hline C & Determinants of a Sustainable Financial Action Plan & \\
\hline $\mathrm{C}_{1}$ & Business strategic plan & \\
\hline $\mathrm{C}_{2}$ & Organizational capacity & \\
\hline$C_{3}$ & Financial condition and technical capacity & \\
\hline$C_{4}$ & Cooperation with external parties & \\
\hline$C_{5}$ & Communication strategies & \\
\hline C 6 & Monitoring, evaluation and mitigation systems & \\
\hline$C_{7}$ & Government policy & 7 \\
\hline $\mathrm{D}$ & Priority and description of the Sustainable Financial Action Plan & \\
\hline D 1 & Rationale & \\
\hline D 2 & Activities & \\
\hline D 3 & Resources & \\
\hline D 4 & Program Implementation Evaluation System & \\
\hline D 5 & Challenges and Future Plans & 5 \\
\hline $\mathrm{E}$ & Follow up on the Sustainable Financial Action Plan & \\
\hline E 1 & Employees, officials and or work units responsible for monitoring and evaluation & \\
\hline E 2 & Determining the time to measure the realization of the RAKB. & \\
\hline E 3 & Follow-up actions from the RAKB. & \\
\hline \multirow[t]{2}{*}{ E 4} & $\begin{array}{l}\text { Risk mitigation in the case of RAKB cannot be carried out properly or does not achieve the desired } \\
\text { objectives }\end{array}$ & 4 \\
\hline & Total & 23 \\
\hline
\end{tabular}

Source: Financial Services Authority (2017) 
a core capital of at least IDR 5 trillion to at least IDR 30 trillion. The BUKU 4 bank is a bank that has a core capital of at least IDR 30 trillion.

Twenty-three components must be met by banks to be able to make RAKB. If the bank discloses 23 components, this means that the bank has been able to fulfill what is required in POJK 51 of 2017. Regarding the theme and items, the POJK Sustainability Report states that it can be made separately or as part of an annual report that must contain information as in Table 2.

Table 2 Components of SR

\begin{tabular}{llc}
\hline No. & \multicolumn{1}{c}{ Information Must Disclose } & Total \\
\hline 1 & Explanation of sustainability strategies & 1 \\
2 & Overview of aspects of sustainability (economic, social, and environment) & 10 \\
3 & Brief profile of LJK, Issuers and Public Companies & 9 \\
4 & Explanation of the Directors & 10 \\
5 & Sustainability governance & 6 \\
6 & Sustainability performance & 18 \\
7 & Written verification from an independent party, if any \\
8 & A feedback sheet for the reader, if any & 1 \\
9 & LJK, Issuer, or Public Company response to feedback from the previous year's report & 1 \\
& Total & 57 \\
\hline
\end{tabular}

Source: Financial Services Authority (2017)

Furthermore, the conformity index to the RAKB and Sustainability Report will be calculated based on how many items are fulfilled by each bank divided by items that should be fulfilled by the bank.

$$
\text { Conformity index }=\frac{\text { Number of items disclose }}{\text { The number of items that should disclose }}
$$

Based on this index, it can identify how far the BUKU 3 and BUKU 4 banks are ready to implement POJK number 51 of 2017.

\section{RESULTS AND DISCUSSION}

Table 3 provides an overview of the financial characteristics of the banks that are the objectives of this research study.

Table 3 Financial Characteristics of BUKU 3 and BUKU 4 Banks

\begin{tabular}{lcccc}
\hline \multicolumn{1}{c}{ Bank } & Asset (Billion) & CAR & ROA & ROE \\
\hline Bukopin & 106,400 & $10.52 \%$ & $0.90 \%$ & $1.85 \%$ \\
Jatim & 51,520 & $23 \%$ & $3.12 \%$ & $17.43 \%$ \\
Jateng & 61,450 & $20.41 \%$ & $2.69 \%$ & $22.08 \%$ \\
BSM & 87,940 & $15.86 \%$ & $0.59 \%$ & $5.68 \%$ \\
Bank DKI & 51,417 & $29.9 \%$ & $2.0 \%$ & $10.1 \%$ \\
Bank OCBC NISP & 153,800 & $17.5 \%$ & $2.0 \%$ & $10.7 \%$ \\
Bank Jabar Banten & 114,980 & $18.77 \%$ & $2.01 \%$ & $20.05 \%$ \\
BCA & 750,320 & $23.10 \%$ & $3.90 \%$ & $19.20 \%$ \\
BNI & 709,330 & $18.50 \%$ & $2.70 \%$ & $15.60 \%$ \\
BRI & $1,126,248$ & $22.96 \%$ & $3.69 \%$ & $20.03 \%$ \\
CIMB & 266,000 & $18.60 \%$ & $1.70 \%$ & $8.30 \%$ \\
Mandiri & $1,124,700$ & $23.18 \%$ & $2.72 \%$ & $14.53 \%$ \\
\hline
\end{tabular}


The data in Tables 4 and 5 show the extent to which BUKU 3 and BUKU 4 banks can meet the requirements of the $\mathrm{OJK}$ regarding the obligation to make a sustainable financial action plan, which is mandated by POJK number 51 of 2017. POJK number 51 of 2017 requires BUKU 3 and BUKU 4 banks to make a sustainable financial action plan (RAKB).

Table 4 Conformity Index of RAKB BUKU 3 and BUKU 4 Banks

\begin{tabular}{llc}
\hline No & \multicolumn{1}{c}{ Banks } & Conformity index of RAKB \\
\hline 1 & Bukopin & $91.30 \%$ \\
2 & Jatim & $86.96 \%$ \\
3 & Jateng & $91.30 \%$ \\
4 & Bank Mandiri Syariah & $86.96 \%$ \\
5 & Bank DKI & $86.96 \%$ \\
6 & Bank OCBC & $86.96 \%$ \\
7 & Bank Jabar Banten & $86.96 \%$ \\
8 & BRI & $95.65 \%$ \\
9 & BNI & $95.65 \%$ \\
10 & Mandiri & $95.65 \%$ \\
11 & BCA & $95.65 \%$ \\
12 & CIMB & $95.65 \%$ \\
\hline
\end{tabular}

Table 5 Conformity Index of Sustainable Report (SR) BUKU 3 and BUKU 4 Banks

\begin{tabular}{llc}
\hline No & \multicolumn{1}{c}{ Banks } & Conformity Index (SR) \\
\hline 1 & Bukopin & $77.19 \%$ \\
2 & Jatim & $75.44 \%$ \\
3 & Jateng & $91.23 \%$ \\
4 & Bank Syariah Mandiri & $87.72 \%$ \\
5 & Bank DKI & $80.70 \%$ \\
6 & Bank OCBC & $80.70 \%$ \\
7 & Bank Jabar Banten & $84.21 \%$ \\
8 & BRI & $91.23 \%$ \\
9 & BNI & $92.98 \%$ \\
10 & Mandiri & $92.98 \%$ \\
11 & BCA & $85.96 \%$ \\
12 & CIMB & $95.92 \%$ \\
\hline
\end{tabular}

Based on the data, BUKU 3 and BUKU 4 banks have reached more than $80 \%$ in compliance with POJK regulations. The lowest conformity index is $86.5 \%$. In BUKU 4 , four banks even reached $95.65 \%$.

The data in Table 6 show the value of the conformity of the contents of each bank's SR with POJK 51/2017. For BUKU 3 banks, the sustainability reporting conformity index is in the range of $75-90 \%$. There is only one bank whose conformity index is above 90\%, namely Central Java (91.23\%). The bank that has the lowest conformity index is the East Java bank (75.44\%). In BUKU 4, the highest sustainability reporting conformity index was at CIMB bank (95.2\%), while the lowest conformity index was at BCA bank (85.96\%). The BCA conformity index is still lower than some BUKU 3 banks, such as Central Java and Bank Syariah Mandiri. These data show that there are still BUKU 4 banks that have a lower conformity value than BUKU 3 banks. 
Table 6 Sustainability Reporting Component Conformity Priority (BUKU 3 Banks)

\begin{tabular}{llc}
\hline No & \multicolumn{1}{c}{ Component } & Average Index \\
\hline 1 & Sustainability governance & $100.0 \%$ \\
2 & Written verification from an independent party, if any & $90.0 \%$ \\
3 & Bank response to feedback from the previous year's report & $82.9 \%$ \\
4 & Explanation of the directors & $80.2 \%$ \\
5 & Brief profile of the bank & $78.6 \%$ \\
6 & Explanation of sustainability strategies & $57.1 \%$ \\
7 & Sustainability performance & $42.9 \%$ \\
8 & Overview of aspects of sustainability (economic, social, and environment) & $42.9 \%$ \\
9 & A feedback sheet for the reader, if any & $0.0 \%$ \\
\hline
\end{tabular}

Furthermore, this study ranks the priority of the SR component based on the average conformity index data for the two bank groups. It is crucial to identify which components are the most fulfilled by the two bank groups.

Table 7 shows the priority or sequence of components of the SR in the BUKU 3 bank group based on the average conformity value. Based on the average conformity index, the BUKU 3 bank group places the bank's brief profile component at the priority, followed by an overview of sustainability aspects and the directors' explanations at the second and third priorities. Furthermore, the components which are the substance of the SR, namely sustainability performance, sustainability management, and sustainability strategy, are in the next sequence. As for the feedback sheet, written verification, and bank responses to the feedback are in the last three sequences.

Table 7 Sustainability Reporting Component Conformity Priority (BUKU 4 Banks)

\begin{tabular}{llc}
\hline No & \multicolumn{1}{c}{ Component } & Average Index (\%) \\
\hline 1 & Explanation of sustainability strategies & 100 \\
2 & Brief profile of bank & 100 \\
3 & Sustainability Governance & 97 \\
4 & Explanation of the directors & 94 \\
5 & Overview of aspects of sustainability (economic, social, and environment) & 92 \\
6 & Sustainability performance & 87 \\
7 & A feedback sheet for the reader, if any & 80 \\
8 & Written verification from an independent party, if any & 20 \\
9 & Bank response to feedback from the previous year's report & 0 \\
\hline
\end{tabular}

In the BUKU 4 bank group, the priority of the SR component is an explanation of the sustainability strategy, and a brief profile of the bank. The second and third priorities are sustainability management and the director's explanation, followed by an overview of sustainability aspects and performance. The last two components are written verification and bank responses to feedback.

The following analysis illustrates the conformity index of RAKB and SR based on the bank's financial characteristics, which include total assets, CAR / KPPM, ROA, ROE. This analysis provides an overview of how the financial characteristics of banks that have a RAKB and SR conformity index above $90 \%$ and below $90 \%$. Compliance levels above $90 \%$ indicate that banks only need to increase their commitment to OJK regulations a little more, while banks that have a compliance rate of less than $90 \%$ require more effort and focus on meeting 
OJK rules. Bearing in mind that POJK regulation number 51 of 2017 requires BUKU 3 and BUKU 4 bank groups to apply this rule in 2019 .

The data in Table 8 shows that $60 \%$ of banks that have a Sustainable Financial Action Plan (RAKB) index of less than $90 \%$ have ROA of less or equal to $2 \%$. While $71.4 \%$ of banks that have a sustainable financial action plan (RAKB) index above $90 \%$ have a higher ROA (above $2 \%$ ). This finding shows that groups of banks that have a lower sustainable financial action plan (RAKB) index also tend to have lower ROA. In contrast, banks with better sustainable financial action plan (RAKB) conformity levels tend to have higher ROA values.

Table 8 RAKB * ROA Cross-tabulation

\begin{tabular}{|c|c|c|c|c|}
\hline & & \multicolumn{2}{|c|}{ ROA } & \multirow[t]{2}{*}{ Total } \\
\hline & & $\leq 2$ & $>2$ & \\
\hline \multicolumn{5}{|l|}{ RAKB } \\
\hline \multirow[t]{3}{*}{$\leq 90$} & Count & 3 & 2 & 5 \\
\hline & $\%$ within RAKB & $60.0 \%$ & $40.0 \%$ & $100.0 \%$ \\
\hline & $\%$ of Total & $25.0 \%$ & $16.7 \%$ & $41.7 \%$ \\
\hline \multirow[t]{3}{*}{$>90$} & Count & 2 & 5 & 7 \\
\hline & $\%$ within RAKB & $28.6 \%$ & $71.4 \%$ & $100.0 \%$ \\
\hline & $\%$ of Total & $16.7 \%$ & $41.7 \%$ & $58.3 \%$ \\
\hline \multirow[t]{3}{*}{ Total } & Count & 5 & 7 & 12 \\
\hline & \% within RAKB & $41.7 \%$ & $58.3 \%$ & $100.0 \%$ \\
\hline & $\%$ of Total & $41.7 \%$ & $58.3 \%$ & $100.0 \%$ \\
\hline
\end{tabular}

The cross-tabulation in Table 9 illustrates that $60 \%$ of bank groups that have a sustainable financial action plan (RAKB) of less than $90 \%$ have ROE of less than $15 \%$. Meanwhile, $57.1 \%$ of banks that have a sustainable financial action plan (RAKB) above $90 \%$ have ROE greater or equal to $15 \%$ (Table 10).

Table 9 RAKB * ROE Cross-tabulation

\begin{tabular}{|c|c|c|c|c|}
\hline & & \multicolumn{2}{|c|}{ ROE } & \multirow[t]{2}{*}{ Total } \\
\hline & & $<15$ & $\geq 15$ & \\
\hline \multicolumn{5}{|l|}{ RAKB } \\
\hline \multirow[t]{3}{*}{$\leq 90$} & Count & 3 & 2 & 5 \\
\hline & $\%$ within RAKB & $60.0 \%$ & $40.0 \%$ & $100.0 \%$ \\
\hline & $\%$ of Total & $25.0 \%$ & $16.7 \%$ & $41.7 \%$ \\
\hline \multirow[t]{3}{*}{$>90$} & Count & 3 & 4 & 7 \\
\hline & $\%$ within RAKB & $42.9 \%$ & $57.1 \%$ & $100.0 \%$ \\
\hline & $\%$ of Total & $25.0 \%$ & $33.3 \%$ & $58.3 \%$ \\
\hline \multirow[t]{3}{*}{ Total } & Count & 6 & 6 & 12 \\
\hline & $\%$ within RAKB & $50.0 \%$ & $50.0 \%$ & $100.0 \%$ \\
\hline & $\%$ of Total & $50.0 \%$ & $50.0 \%$ & $100.0 \%$ \\
\hline
\end{tabular}


Table 10 RAKB * Asset Cross-tabulation

\begin{tabular}{llccc}
\hline & & \multicolumn{2}{c}{ Asset } & Total \\
\cline { 3 - 4 } & & $<700.000 \mathrm{M}$ & $\geq 700.000 \mathrm{M}$ & \\
\hline RAKB & & & & \\
$\leq 90$ & Count & 5 & 0 & 5 \\
& \% within RAKB & $100.0 \%$ & $0.0 \%$ & $100.0 \%$ \\
& \% of Total & $41.7 \%$ & $0.0 \%$ & $41.7 \%$ \\
$>90$ & Count & 3 & 4 & 7 \\
& \% within RAKB & $42.9 \%$ & $57.1 \%$ & $100.0 \%$ \\
& \% of Total & $25.0 \%$ & $33.3 \%$ & $58.3 \%$ \\
Total & Count & 8 & 4 & 12 \\
& \% within RAKB & $66.7 \%$ & $33.3 \%$ & $100.0 \%$ \\
& \% of Total & $66.7 \%$ & $33.3 \%$ & $100.0 \%$ \\
\hline
\end{tabular}

Furthermore, the identification of the conformity of the sustainable financial action plan (RAKB) with the total assets owned by banks shows that 100\% of banks that have a sustainable financial action plan (RAKB) less than $90 \%$ have assets of less than 7 trillion rupiahs. Whereas $57.1 \%$ of banks that have a sustainable financial action plan (RAKB) above $90 \%$ have total assets above 7 trillion rupiahs (Table 11).

Table 11 RAKB * CAR Cross-tabulation

\begin{tabular}{|c|c|c|c|c|}
\hline & & \multicolumn{2}{|c|}{ CAR } & \multirow[t]{2}{*}{ Total } \\
\hline & & $\leq 20$ & $>20$ & \\
\hline \multicolumn{5}{|l|}{ RAKB } \\
\hline \multirow[t]{3}{*}{$\leq 90$} & Count & 3 & 2 & 5 \\
\hline & $\%$ within RAKB & $60.0 \%$ & $40.0 \%$ & $100.0 \%$ \\
\hline & $\%$ of Total & $25.0 \%$ & $16.7 \%$ & $41.7 \%$ \\
\hline \multirow[t]{3}{*}{$>90$} & Count & 3 & 4 & 7 \\
\hline & $\%$ within RAKB & $42.9 \%$ & $57.1 \%$ & $100.0 \%$ \\
\hline & $\%$ of Total & $25.0 \%$ & $33.3 \%$ & $58.3 \%$ \\
\hline \multirow[t]{3}{*}{ Total } & Count & 6 & 6 & 12 \\
\hline & $\%$ within RAKB & $50.0 \%$ & $50.0 \%$ & $100.0 \%$ \\
\hline & $\%$ of Total & $50.0 \%$ & $50.0 \%$ & $100.0 \%$ \\
\hline
\end{tabular}

When an analysis based on the capital adequacy ratio (CAR/KPPM) carried out, $60 \%$ of banks that had a sustainable financial action plan (RAKB) conformity of less than $90 \% \mathrm{t}$ had a CAR ratio of less than $20 \%$. While $57.1 \%$ of bank groups that have sustainable financial action plan (RAKB) conformity above $90 \%$ have CAR/KPPM values above $20 \%$.

\section{Sustainability Reporting Financial Characteristics}

Then the same analysis is also carried out on the conformity of sustainability reporting with the financial characteristics of banks, including total assets, CAR/KPPM, ROA, and ROE (Table 12). 
Table 12 SR Index * CAR Cross-tabulation

\begin{tabular}{|c|c|c|c|c|}
\hline & & \multicolumn{2}{|c|}{ CAR } & \multirow[t]{2}{*}{ Total } \\
\hline & & $\leq 20$ & $>20$ & \\
\hline \multicolumn{5}{|c|}{ SR Index } \\
\hline \multirow[t]{3}{*}{$\leq 90$} & Count & 3 & 2 & 5 \\
\hline & $\%$ within SR Index & $60.0 \%$ & $40.0 \%$ & $100.0 \%$ \\
\hline & $\%$ of Total & $25.0 \%$ & $16.7 \%$ & $41.7 \%$ \\
\hline \multirow[t]{3}{*}{$>90$} & Count & 3 & 4 & 7 \\
\hline & $\%$ within SR Index & $42.9 \%$ & $57.1 \%$ & $100.0 \%$ \\
\hline & $\%$ of Total & $25.0 \%$ & $33.3 \%$ & $58.3 \%$ \\
\hline \multirow[t]{3}{*}{ Total } & Count & 6 & 6 & 12 \\
\hline & $\%$ within SR Index & $50.0 \%$ & $50.0 \%$ & $100.0 \%$ \\
\hline & $\%$ of Total & $50.0 \%$ & $50.0 \%$ & $100.0 \%$ \\
\hline
\end{tabular}

The cross-tabulation data above shows that $60 \%$ of the bank groups that have a sustainability reporting conformity of less than $90 \%$ have a CAR of less than $20 \%$. While the bank group that has sustainability reporting conformity above $90 \%$ has $57.1 \%$, having CAR above $20 \%$ (Table 13 ).

Table 13 SR Index * Asset Cross-tabulation

\begin{tabular}{|c|c|c|c|c|}
\hline & & \multicolumn{2}{|c|}{ Asset } & \multirow[t]{2}{*}{ Total } \\
\hline & & $<700.000 M$ & $\geq 700.000 \mathrm{M}$ & \\
\hline \multicolumn{5}{|c|}{ SR Index } \\
\hline \multirow[t]{3}{*}{$\leq 90$} & Count & 5 & 0 & 5 \\
\hline & $\%$ within SR Index & $100.0 \%$ & $0.0 \%$ & $100.0 \%$ \\
\hline & $\%$ of Total & $41.7 \%$ & $0.0 \%$ & $41.7 \%$ \\
\hline \multirow[t]{3}{*}{$>90$} & Count & 3 & 4 & 7 \\
\hline & $\%$ within SR Index & $42.9 \%$ & $57.1 \%$ & $100.0 \%$ \\
\hline & $\%$ of Total & $25.0 \%$ & $33.3 \%$ & $58.3 \%$ \\
\hline \multirow[t]{3}{*}{ Total } & Count & 8 & 4 & 12 \\
\hline & $\%$ within SR Index & $66.7 \%$ & $33.3 \%$ & $100.0 \%$ \\
\hline & $\%$ of Total & $66.7 \%$ & $33.3 \%$ & $100.0 \%$ \\
\hline
\end{tabular}

The cross-tabulation data between the sustainability reporting conformity index and the total assets show that all banks that have a sustainability reporting index of less than $90 \%$ have assets of less than 7 trillion. In contrast, $57.1 \%$ of banks that have a sustainability reporting index above $90 \%$ have assets above 7 trillion (Table 14).

Table 14 SR Index * ROA Cross-tabulation

\begin{tabular}{|c|c|c|c|c|}
\hline & & \multicolumn{2}{|c|}{ ROA } & \multirow[t]{2}{*}{ Total } \\
\hline & & $\leq 2$ & $>2$ & \\
\hline \multicolumn{5}{|c|}{ SR Index } \\
\hline \multirow{3}{*}{$\leq 90$} & Count & 3 & 2 & 5 \\
\hline & $\%$ within SR Index & $60.0 \%$ & $40.0 \%$ & $100.0 \%$ \\
\hline & $\%$ of Total & $25.0 \%$ & $16.7 \%$ & $41.7 \%$ \\
\hline \multirow[t]{3}{*}{$>90$} & Count & 2 & 5 & 7 \\
\hline & $\%$ within SR Index & $28.6 \%$ & $71.4 \%$ & $100.0 \%$ \\
\hline & $\%$ of Total & $16.7 \%$ & $41.7 \%$ & $58.3 \%$ \\
\hline \multirow[t]{3}{*}{ Total } & Count & 5 & 7 & 12 \\
\hline & $\%$ within SR Index & $41.7 \%$ & $58.3 \%$ & $100.0 \%$ \\
\hline & $\%$ of Total & $41.7 \%$ & $58.3 \%$ & $100.0 \%$ \\
\hline
\end{tabular}


The data above show the results of the cross-tabulation between the sustainability reporting index and the ROA value of each bank. Sixty percent of banks that have a sustainability reporting index of less than 90 percent of their ROA value is less than or equal to two percent. Meanwhile, 71.4 percent of banks that have a sustainability reporting index above 90 percent show ROA values above two percent Table 15.

Table 15 SR Index * ROE Cross-tabulation

\begin{tabular}{|c|c|c|c|c|}
\hline & & \multicolumn{2}{|c|}{ ROE } & \multirow[t]{2}{*}{ Total } \\
\hline & & $<15$ & $\geq 15$ & \\
\hline \multicolumn{5}{|c|}{ SR Index } \\
\hline \multirow[t]{3}{*}{$\leq 90$} & Count & 3 & 2 & 5 \\
\hline & $\%$ within SR index & $60.0 \%$ & $40.0 \%$ & $100.0 \%$ \\
\hline & $\%$ of Total & $25.0 \%$ & $16.7 \%$ & $41.7 \%$ \\
\hline \multirow[t]{3}{*}{$>90$} & Count & 3 & 4 & 7 \\
\hline & $\%$ within SR index & $42.9 \%$ & $57.1 \%$ & $100.0 \%$ \\
\hline & $\%$ of Total & $25.0 \%$ & $33.3 \%$ & $58.3 \%$ \\
\hline \multirow[t]{3}{*}{ Total } & Count & 6 & 6 & 12 \\
\hline & $\%$ within SR index & $50.0 \%$ & $50.0 \%$ & $100.0 \%$ \\
\hline & $\%$ of Total & $50.0 \%$ & $50.0 \%$ & $100.0 \%$ \\
\hline
\end{tabular}

Furthermore, cross-tabulation between sustainability reporting index and ROE also carried out, the results of which showed that 60 percent of the bank group with a sustainability reporting index of less than 90 percent had an ROE value of less than 15 percent. In contrast, the bank group with a sustainability reporting index above 90 percent had ROE above 15 percent.

Based on the cross-tabulation data it can conclude that: the majority of banks that have high conformity of sustainable financial action plans and SRs (above 90\%) also have high ROA and ROE values compared to banks that have low conformity of sustainable financial action plans and SR (<90\%). Besides, the results of the cross-tabulation also illustrate that the majority of banks that have a higher sustainable financial action plan (RAKB) and SRs conformity also have more significant total assets. A higher CAR/KPPM value also followed it.

Several studies (Ali et al., 2017; Gamerschlag et al., 2011; Mallin et al., 2014; Udayasankar, 2008) use financial characteristics as a factor determinants of corporate social responsibility (CSR) activities show identical results. These studies find that financial characteristics influence the corporate social responsibility index. Although sustainability activities are more than just CSR because they have a broader and more profound dimension, but at least what obtained from this research is in line with what has been found by previous researchers.

However, the cross-tabulation data above has not been able to show a correlation between sustainable financial action plan (RAKB) and SRs index with each financial characteristic due to the limited sample (only 12). However, these data at least provide an overview of the financial characteristics of the banks studied. To find out the correlation between the sustainable financial action plan (RAKB) and SR index, more samples are needed (minimum 20).

On average, the conformity of the contents of the reports made by banks with the components required in POJK number 51 of 2017 regarding the sustainable financial action plan and SR both in the BUKU 3 and BUKU 4 bank groups have not met $100 \%$ what is required by the POJK.

In the BUKU 3 bank group, the level of conformity of the sustainable financial action plan (RAKB) was still at $88.2 \%$, while the conformity of the SR was at the level of $82.46 \%$. In the BUKU 4 bank group, the conformity 
level of the sustainable financial action plan (RAKB) was $95.65 \%$, and for the SR, it was $92.17 \%$. Although it has not fully met the requirement in POJK number 51 of 2017, the level of conformity of both sustainable financial action plan (RAKB) and SR can already be said to meet $90 \%$ of what is requested by the POJK to fulfill the commitment to sustainable finance that has been required by the FSA in 2019 for BUKU 3 and BUKU 4 banks requires a little more commitment. The legitimacy theory says that the better the efforts made by the company to meet the expectations of its stakeholders, the legitimacy obtained by the company will also be stronger.

\section{CONCLUSION}

The three components in the SR that best meet the compliance with POJK number 51 of 2017 in the BUKU 3 bank group are a brief profile of the bank, an overview of sustainability aspects (economic, social, and environmental) and an explanation of the directors. In BUKU 4 bank group are an explanation of the sustainability strategy, a brief profile of the bank, and sustainability management. Components that have not fulfilled what is required by the OJK both for the SR in the BUKU 3 and BUKU 4 groups are regarding the feedback sheet for the reader, the bank's response to the feedback of the previous year's report and written verification from the independent party. The analysis also found that the average bank that has a good sustainable financial action plan and the SR conformity (above 90\%) also has higher asset value, CAR/KPPM, ROA and ROE ratios than banks that have lower conformity for a sustainable financial action plan and the SR. This study has limitations in terms of small sample sizes, so it cannot produce statistical tests, especially to prove the relationship between financial characteristics and the conformity of the sustainable financial action plan (RAKB) and the SR. Future studies may be able to expand the number of banks studied to ensure the relationship between sustainable financial action plan (RAKB) and the SR with the financial characteristics of the bank concerned.

\section{ORCID}

Inten Meutia (10) http://orcid.org/0000-0002-2418-0283

Zulnaidi Yaacob (1D) http://orcid.org/0oo0-0002-1222-1949

\section{REFERENCES}

Ali, W., Frynas, J. G., \& Mahmood, Z. (2017). Determinants of Corporate Social Responsibility (CSR) disclosure in developed and developing countries: A literature review. Corporate Social Responsibility and Environmental Management, 24(4), 273-294, https://doi.org/10.1002/csr.1410.

Aliyu, S., Hassan, M. K., Mohd Yusof, R., \& Naiimi, N. (2016). Islamic Banking sustainability: A review of literature and directions for future research. Emerging Markets Finance and Trade, 53(2), 440-470. https://doi.org/ 10.1080/1540496X.2016.1262761.

Alves, M. T. V. D. (2011). Content analysis: Its use in accounting publications. Revista Universo Contábil, pp. 146-166. http://proxy.furb.br/ojs/index.php/universocontabil/article/view/2266

Beck, A. C., Campbell, D., \& Shrives, P. J. (2010). Content analysis in environmental reporting research: Enrichment and rehearsal of the method in a British-German context. British Accounting Review, 42(3), 207-222, https://doi.org/10.1016/j.bar.2010.05.002.

Deegan, C. (2014). An overview of legitimacy theory as applied within the social and environmental accounting literature. In Sustainability accounting and accountability, 2nd Edition, (2014), Routledge, 248-272. Retrieved from https://researchbank.rmit.edu.au/view/rmit:29494. 
Financial Services Authority (2017). Peraturan OJK Nomor 51/ 2017 tentang Penerapan Keuangan Berkelanjutan.

Frazier, K. B., Ingram, R. W., \& Tennyson, B. M. (1984). A methodology for the analysis of narrative accounting disclosures. Journal of Accounting Research, 22(1), 318. https://www.jstor.org/stable/2490713?origin= crosSustainability Reporting (SR)ef

Gamerschlag, R., Möller, K., \& Verbeeten, F. (2011). Determinants of voluntary sustainability reporting (SR) disclosure: empirical evidence from Germany. Review of Managerial Science, 5(2-3), 233-262. http:/link. springer.com/10.1007/s11846-010-0052-3.

Hadad, M. D. \& Maftuchah, I. (2015). Sustainable Financing. Jakarta: PT Elex Media Komputindo.

Hashim, F., Mahadi, N. D., \& Amran, A. (2015). Corporate governance and sustainability practices in Islamic Financial Institutions: The role of country of origin. Procedia Economics and Finance, 31, 36-43. https://linkinghub.elsevier.com/retrieve/pii/S2212567115011296

High-Level Expert Group on Sustainable Finance (2018). Sustainable European economy. European Commission. Jameson, C. M. (2012). Silent Spring revisited (1st ed.). Bloomsburry Publishing Plc.

Jeucken, M. (2001). Sustainable finance and banking-The financial sector and the future of the plant (1st ed.). Earthscan Publications Ltd.

Krippendorff, K. (2004). Reliability in content analysis. Human Communication Research, 30(3), 411-433. https://academic.oup.com/hcr/article/30/3/411-433/4331534

Kumar, K., \& Prakash, A. (2018). Developing a framework for assessing sustainable banking performance of the Indian banking sector. Social Responsibility Journal, https://www.emeraldinsight.com/doi/ 10.1108/SUSTAINABILITY REPORTING (SR)J-07-2018-0162

Lindblom, C. K. (1994). The implications of organizational legitimacy for corporate social performance and disclosure. [Paper Presented at the Critical Perspectives on Accounting Conference]. Working Paper for the American Accounting Association Public Interest Section, USA.

Mallin, C., Farag, H., \& Ow-Yong, K. (2014). Corporate social responsibility and financial performance in Islamic banks. Journal of Economic Behavior \& Organization, 103, S21-S38. https://doi.org/10.1016/j.jebo. 2014.03.001

Manurung, A. M., \& Basuki, H. (2010). An analytical assessment of assurance practices in social environmental and sustainable reporting in the United Kingdom and North America. Gadjah Mada International Journal of Business, 12(1), 75-115, https://doi.org/10.22146/gamaijb.5513.

Meutia, I., \& Putra, B. C. (2017). Narrative accounting practices in Indonesia companies. Binus Business Review, 8(1), 77, https://doi.org/10.21512/bbr.v8i1.1944.

Pratiwi, A. (2016). Islamic banking contribution in sustainable socioeconomic development in Indonesia. Humanomics, 32(2), 98-120, https://doi.org/10.1108/H-12-2015-0085.

Shamshad, M., Sarim, M., Akhtar, A., \& Tabash, M. I. (2018). Identifying critical success factors for sustainable growth of Indian banking sector using interpretive structural modeling (ISM). International Journal of Social Economics, 45(8), 1189-1204, https://doi.org/10.1108/IJSE-10-2017-0436.

Soppe, A. (2004). Sustainable Corporate Finance. Journal of Business Ethics, 53(1/2), 213-224. http:/link.springer. com/10.1023/B:BUSI.0000039410.18373.12

Suchman, M. C. (1995). Managing legitimacy: Strategic and institutional approaches. Academy of Management Review, 20(3), 571-610. http://journals.aom.org/doi/10.5465/amr.1995.9508080331

Sydserff, R., \& Weetman, P. (2002). Developments in content analysis: A transitivity index and DICTION scores. Accounting, Auditing \& Accountability Journal, 15(4), 523-545, https://doi.org/10.1108/ 09513570210440586.

Tan, L. H., Chew, B. C., \& Hamid, S. R. (2017). Service quality implementation in shaping sustainable banking operating system: A case study of Maybank Group. Qualitative Research in Financial Markets, 9(4), 359-381, https://doi.org/10.1108/QRFM-01-2017-0002.

Udayasankar, K. (2008). Corporate social responsibility and firm size. Journal of Business Ethics, 83(2), 167-175. http://link.springer.com/10.1007/s10551-007-9609-8 
Unerman, J. (2000). Methodological issues-Reflections on quantification in corporate social reporting content analysis. Accounting, Auditing \& Accountability Journal, 13(5), 667-681, https://doi.org/10.1108/ 09513570010353756.

United Nations World Commission on Environment and Development (1987). Brundtland report: Our common future. United Nations. http://www.un-documents.net/our-common-future.pdf

Wolfson, A., Tavor, D., \& Mark, S. (2013). Sustainability as service. Sustainability Accounting, Management and Policy Journal, 4(1), 103-114. http://www.emeraldinsight.com/doi/10.1108/SAMPJ-02-2012-0007 